tions with many bars, and the rays are large and composite or heterogeneous. The natural conclusion is that this wood must be from some species of Ilex.

This finding has since been confirmed by the Forestry Officer of British Guiana.

SAMUEL J. RECORD

YALE UNIVERSITY

\section{SPECIAL ARTICLES GENETICS OF THE VIENNA WHITE RABBIT}

IN the second edition of his text-book ${ }^{1}$, Dr. Erwin Baur described a cross between two white varieties of rabbit which produred colored young. One of the white varieties is the familiar pink-eyed albino, the other is called Vienna White and is described by Baur as differing from the albino variety only in the color of the eyes, which are blue. He explains the production of colored young in this cross as due to the complementary action of two independent color factors, like the well known cases among plants in which a cross between two white-flowered varieties produces progeny bearing colored flowers.

It happens that the colored young rabbit figured by Baur as resulting from the cross was Dutch marked, and this led Punnett to suppose that the blue-eyed white parent was really a Dutch rabbit in which the white areas had attained a maximum extension so as to cover the entire coat. This interpretation seemed reasonable to me until I recently obtained in some breeding experiments animals similar to Baur's Vienna Whites, when it became clear that they have no relation to Dutch marking, and also that the relation of Vienna White to albinism is much closer than Baur had supposed.

The color factor of Vienna White is in fact an allelomorph of albinism. If Baur had used in the cross with Vienna White an albino whose parents were yellow, he would not have obtained colored young but only blue-eyed whites or albinos, which result would have shown that the two white varieties are not due

1 Einführung in die experimentelle Vererbungslehre, Berlin, 1914. to complementary factors but to allelomorphic conditions of one and the same factor.

The case is strictly analogous with that of the silver agouti guinea-pig as worked out by Castle and Wright ${ }^{2}$ several years ago. The so-called color factor has in guinea-pigs several allelomorphic ${ }^{*}$ states, as shown by Wright. The two with which we were then concerned produce respectively (1) the ordinary albino or all-white coat associated with pink-eyes and (2) a condition in which the coat develops black pigment but no yellow pigment, and the eyes are red, not pink. By suitable crosses the gene for yellow coat can be introduced into the red-eyed variety. But since (1) the gene for yellow inhibits the development of black pigment in the coat and (2) the gene for red-eye (the color allelomorph) inhibits the development of yellow in the coat, it follows that the coat, in what is genetically a red-eyed yellow animal, contains neither black nor yellow pigment and so is white. Only the red eye-color then serves to distinguish the animal from an albino. It is in fact a red-eyed white in appearance, but genetically is a red-eyed yellow and if crossed with yellow animals will produce yellow young:

Now in rabbits we have a strictly parallel situation. The chinchilla ${ }^{3}$ rabbit corresponds with the red-eyed silver agouti guinea-pig. Its coat contains black pigment but not yellow. If we cross chinchilla with albino, we obtain chinchilla young, not gray, indicating that chinchilla and albinism are allelomorphs, not complementary factors. If the albino parent carries the gene for yellow coat, then in $F_{2}$ we obtain chinchillas, albinos, and "blue-eyed whites." The last are obviously yellow chinchillas. I have not been able to obtain as yet the Vienna White variety from Europe, but those who have them can easily put this interpretation to the test by crossing Vienna White with a yellow coated variety. If my interpreta. tion is correct, they will obtain yellow young from the cross.

\footnotetext{
2 Carnegie Institution of Wash., Publ. No. 241, 1916.

3 Castle, W. E., Genetics of the chinchilla rabbit, Scrence, April 22, 1921.
} 
But the reader may inquire, how was it that Baur obtained a black-coated rabbit by crossing Vienna White with albino. The answer is that the rabbit which he figured was not an ordinary black but a black chinchilla. Examined critically the coat would, I think, have been found to be not jet black, but sepia, and the eyes to give a red reflection indicating less heavy pigmentation than ordinary black. Baur gives evidence of the less heavy pigmentation of the eye in Vienna White by calling the eye "blue." We have noted the same fact in guineapigs. but have stressed the increased red reflection in calling the eye "red." The nonagouti red-eyed guinea-pig has been called "sepia" by Wright to distinguish it from ordinary black. Similarly one might call the black chinchilla rabbit "sepia." I have obtained such individuals in $F_{2}$ from the cross of chinchilla with albino.

Bussey Institution, FERBUARY 16, 1922.

\section{THE AMERICAN SOCIETY OF AGRONOMY}

The program of the annual meeting held at New Orleans, La., November 7-8, 1921, was as follows:

\section{MoNDAy, November 7}

Symposium on Nitrogen in Its Relation to Soils and Crops

Leader: J. G. Lipman

Our inventory of soil nitrogen: C. F. Marbut.

The effect of timothy on the disappearance of nitrates: JAMES A. BIZZELL.

Nitrogen economy in soils: FIRMAN E. BeAR.

The nitrogen inventory as affected by livestock versus grain farming: C. G. Williams.

Green manuring in relation to the nitrogen content of soils: M. J. FunCHESS.

Nitrogen in relation to crop production in the Middle West: S. D. CoNNER.

The influence of calcic magnesic materials upon the outgo of nitrates in lysimeter leachings: W. H. MACINTIRE.

A glance at the present and future supplies of fertilizer nitrogen: S. B. HASKELL.

Agricultural and commercial values of nitrogenous plant foods: A. W. BLAIR.

\section{Monday Evening}

Annual dinner. Presidential address: "The agronomic placement of varieties," Chas. A. Mooers, agronomist and vice-director, Tennessee Agricultural Experiment Station.

\section{TUESDAy, November 8}

Symposium on Teaching Crops and Soils Courses. Leader: L. E. Call.

Some of the teaching problems of the Southern agronomist: J. R. FAIN.

Progress in standardizing the elementary courses in soils: M. F. MILLER.

A plea for experimental work, on methods in crops teaching: S. B. HASKELL.

What should constitute the recitation work of a five-year course in elementary farm crops: W. C. ETHERIDGE.

Report of the committee on intercollegiate crops contests: A. C. ARNY.

\section{TUesday AFternoon} General Agronomic Papers.

The terminology of the subdivisions of agriculture and some of the broader factors relating to plant production: C. V. PIPER.

The salt requirements of agricultural plants: A. G. MCCALL.

The standardization of field experiments: A. T. Wiancko.

The control of cotton diseases by the use of potash fertilizers: L. E. RAST.

The infuence of fertilizers on yield and maturity of soybeans: GEo. L. Schuster.

A new muck soil problem and its solution: M. E. Sherwin, R. B. Etheridge, A. Dunham.

Soil types as a basis for soil investigations: P. E. Brown.

The potassium-nitrogen ratio of red clover as influenced by potassic fertilizers: PAUL EMERSON, JoHN BARTON.

The following were elected officers of the society for the ensuing year:

L. E. Call, Manhattan, Kansas, president.

D. E. Stephens, Moro, Oregon, first vice-president.

A. B. Conner, College Station, Texas, second vice-president.

P. E. Brown, Ames, Iowa, secretary-treasurer.

C. A. Mooers, Knoxville, Tenn., representative on the Council of the A.A.A. S.

C. F. Marbut, Washington, D. C., representative to the National Research Council.

P. E. Brown, Secretary 